\title{
Investigation and Analysis of Soil Radioactivity Level in Parks in a City
}

\author{
Qiushi Liu, Ruiyang Xu, Yaohan Hu \\ Chengdu University of Technology, Chengdu, China \\ Email:LQS70312@163.com
}

How to cite this paper: Liu, Q.S., Xu, R.Y. and $\mathrm{Hu}, \mathrm{Y} . \mathrm{H}$. (2020) Investigation and Analysis of Soil Radioactivity Level in Parks in a City. Open Access Library Journal, 7: e6656.

https://doi.org/10.4236/oalib.1106656

Received: July 24, 2020

Accepted: August 17, 2020

Published: August 20, 2020

Copyright $\odot 2020$ by author(s) and Open Access Library Inc.

This work is licensed under the Creative Commons Attribution International License (CC BY 4.0).

http://creativecommons.org/licenses/by/4.0/

(c) (i) Open Access

\begin{abstract}
Using a portable microcomputer multi-channel gamma spectrometer to directly measure the radioactive content in the soil, the on-site gamma energy spectrum measurement was carried out on the soil of 7 parks in a certain city. The survey results show that the specific activity of ${ }^{40} \mathrm{k}$ in the urban park soil ranges from $470.88 \mathrm{bq} / \mathrm{kg}$ to $640.2 \mathrm{bq} / \mathrm{kg}$. The specific activity of ${ }^{238} \mathrm{u}$ ranges from $26.77 \mathrm{bq} / \mathrm{kg}$ to $33.31 \mathrm{bq} / \mathrm{kg}$. The specific activity of ${ }^{232}$ th ranges from $42.14 \mathrm{bq} / \mathrm{kg}$ to $54.72 \mathrm{bq} / \mathrm{kg}$. The content of the three radionuclides in the soil in the park is lower than the national average, and far lower than the radioactivity of ordinary building materials.
\end{abstract}

\section{Subject Areas}

Nuclear Physics, Soil Science

\section{Keywords}

Parks, Soil, Natural Radionuclide, Specific Activity

\section{Introduction}

Natural radioactive radiation is the main component of the earth's radioactive and an important part of the human living environment. With people's gradual understanding of radionuclides in nature and the wide application of radionuclides in various fields, the radiation of radionuclides pollution has gradually attracted people's attention [1] [2] [3]. Soil is one of the main radiations that radionuclides transfer to the environment [4]. Measuring the concentration of radionuclides in the soil in a certain area helps to understand the local radioactivity level. Analysis of the activities of various radionuclides in the soil can also 
understand the distribution of nuclides and provide suggestions for public radiation protection [5]. As the first choice for leisure and entertainment in people's daily life, the park is the closest place to nature in the city. Therefore, it is necessary to measure the level of radionuclide in the soil in the park.

\section{Investigation Method}

\subsection{Instrument and Technical Route}

The environmental gamma energy spectrum measurement method uses a gamma spectrometer composed of $\mathrm{NaI}(\mathrm{Tl})$ scintillator detectors as a tool to directly determine the specific activity of radionuclides in environmental soil on site. Its working principle is that the energy deposited by gamma rays produces fluorescence in the scintillator, and the fluorescence emits electrons on the photocathode of the photomultiplier tube, which are then amplified to form a voltage pulse. The more energy deposited by gamma photons, the greater the pulse amplitude of the probe output. The microcomputer multi-channel system analyzes the height distribution of the pulse, and then the energy distribution of the $\gamma$-ray deposited in the scintillator can be obtained. Analyze the obtained gamma spectrum. Then the nuclide information can be extracted [6].

A portable microcomputer multi-channel gamma spectrometer was used to measure the energy spectrum of the park soil, and the high-purity germanium gamma spectrometer was used to measure the laboratory gamma energy spectrum of the park soil samples. According to relevant standards and methods, 7 typical parks in a certain city were selected as the survey target areas. The number of grid measurement points was determined according to the size of the park and the functional planning area of the park, and 350 on-site gamma spectrometry measurements were determined point.

\subsection{Measurement Process}

According to the technical specification of ground gamma spectrometry measurement, first turn on the instrument and preheat the instrument. After preheating, check whether the instrument works normally. After the instrument is stable, the instrument is placed vertically at the point to be measured, which is close to the soil surface. The measurement time is 180 s, and the data is recorded.

\subsection{Quality Assurance}

The portable multi-channel gamma spectrometer used in the experiment is measured through the standard saturation model, and the calibration coefficients of $\mathrm{K}, \mathrm{U}$ and $\mathrm{Th}$ are obtained in the calibration certificate issued by the relevant qualification unit. The calibration method is referred to EJ/T 363-2012 [7]. Before the experiment, the short-term stability of the instrument was checked, and the gamma spectrum was continuously measured at a fixed position. The stability measurement data are shown in Table 1. 
Table 1. Stability measurement data of portable gamma spectrometer.

\begin{tabular}{cccc}
\hline & $\mathrm{K} / \%$ & $\mathrm{U} / \times 10^{-6}$ & $\mathrm{Th} / \times 10^{-6}$ \\
\hline Average & 2.09 & 10.87 & 44.54 \\
Standard Deviation & 0.16 & 0.95 & 1.38 \\
Skewness & 0.501 & 0.501 & 0.501 \\
\hline
\end{tabular}

From the analysis of the measured data, the relative standard deviation of the instrument is less than $10 \%$, and the instrument is stable and meets the specification requirements.

\section{Results}

The multi-channel gamma spectrometer is used to preheat the instrument. After preheating, check whether the instrument works normally. After the instrument is stable, the instrument is placed vertically at the point to be measured, which is close to the soil surface. The measurement time is 180s. The data are recorded and the soil in the park is directly measured, and the contents of three radionuclides ${ }^{40} \mathrm{~K},{ }^{238} \mathrm{U}$, and ${ }^{232} \mathrm{Th}$ were obtained, and the contents of the three radionuclides were converted into specific activities through conversion coefficients. The average value of these three radionuclides is $544 \mathrm{~Bq} / \mathrm{kg}$ for ${ }^{40} \mathrm{~K}, 30.2 \mathrm{~Bq} / \mathrm{kg}$ for ${ }^{238} \mathrm{U}$, and $47.2 \mathrm{~Bq} / \mathrm{kg}$ for ${ }^{232} \mathrm{Th}$. The specific information is shown in Table 2.

The specific activities of ${ }^{40} \mathrm{~K},{ }^{238} \mathrm{U},{ }^{232} \mathrm{Th}$ in soil of each park are shown in Figures 1-3.

It can be seen from the figure that the specific activity of radionuclides in the soil of Park E is higher than that of other parks. However, in the analysis of a single nuclide, the specific activity of ${ }^{40} \mathrm{~K}$ in the soil of Park $\mathrm{E}$ is the highest, which is $640.2 \mathrm{~Bq} / \mathrm{kg}$, the specific activity of ${ }^{238} \mathrm{U}$ in the soil of Park F is the highest, which is $33.31 \mathrm{~Bq} / \mathrm{kg}$, and the specific activity of the soil in Park E is ${ }^{232} \mathrm{Th}$. The highest is $54.72 \mathrm{~Bq} / \mathrm{kg}$. The specific activity of ${ }^{40} \mathrm{~K}$ in the soil of Park A was the lowest at $470.88 \mathrm{~Bq} / \mathrm{kg}$, the specific activity of ${ }^{238} \mathrm{U}$ in the soil of Park D was the lowest at $26.77 \mathrm{~Bq} / \mathrm{kg}$, and the specific activity of ${ }^{232} \mathrm{Th}$ in the soil of Park C was the lowest at $42.14 \mathrm{~Bq} / \mathrm{kg}$.

The survey results of this study show that there are certain differences in the content of radionuclides in the soil of different parks, but the differences are not significant. The radionuclide content in the park is compared with the national average, as shown in Table 3 [8] [9].

As can be seen from the table, the three types of soil radionuclide content in the city's open parks are all lower than the national average.

\section{Conclusions}

1) After measuring the radionuclide content of 7 parks in the city, the results show that the natural radioactivity level of the city park environment is not high, and the specific activity content of ${ }^{40} \mathrm{~K}$ in the park soil ranges from $470.88 \mathrm{~Bq} / \mathrm{kg}$ 
Table 2. Results of radionuclide survey in the park.

\begin{tabular}{|c|c|c|c|c|c|}
\hline Park Name & Nuclide & $\begin{array}{l}\text { Average specific } \\
\text { activity }(\mathrm{Bq} / \mathrm{kg})\end{array}$ & Maximum & Minimum & $\begin{array}{l}\text { Standard } \\
\text { Deviation }\end{array}$ \\
\hline & $\mathrm{K}-40$ & 470.88 & 635.39 & 284.83 & 57.33 \\
\hline \multirow[t]{3}{*}{ Park A } & $\mathrm{U}-238$ & 28.36 & 60.39 & 16.67 & 6.61 \\
\hline & Th-232 & 49.22 & 74.14 & 24.44 & 7.57 \\
\hline & $\mathrm{K}-40$ & 476.01 & 760.59 & 194.06 & 108.64 \\
\hline \multirow[t]{3}{*}{ Park B } & U-238 & 30.06 & 43.84 & 15.56 & 6.31 \\
\hline & Th-232 & 43.54 & 59.64 & 20.34 & 10.12 \\
\hline & $\mathrm{K}-40$ & 473.19 & 907.7 & 153.37 & 157.34 \\
\hline \multirow[t]{3}{*}{ Park C } & U-238 & 31.28 & 47.79 & 13.71 & 6.42 \\
\hline & Th-232 & 42.14 & 63.99 & 16.32 & 11.03 \\
\hline & $\mathrm{K}-40$ & 522.96 & 613.48 & 400.64 & 47.7 \\
\hline \multirow[t]{3}{*}{ Park D } & U-238 & 26.77 & 41.87 & 11.12 & 5.37 \\
\hline & Th-232 & 44.46 & 55.74 & 28.91 & 6.87 \\
\hline & $\mathrm{K}-40$ & 640.02 & 1020.38 & 338.04 & 160.94 \\
\hline \multirow[t]{3}{*}{ Park E } & U-238 & 33.13 & 81.02 & 16.18 & 12.84 \\
\hline & Th-232 & 54.72 & 119.49 & 25.17 & 18.4 \\
\hline & $\mathrm{K}-40$ & 610.48 & 1292.69 & 391.25 & 146.82 \\
\hline \multirow[t]{3}{*}{ Park F } & $\mathrm{U}-238$ & 33.31 & 54.34 & 18.65 & 7.14 \\
\hline & Th-232 & 48.38 & 65.24 & 23.1 & 8.62 \\
\hline & $\mathrm{K}-40$ & 615.86 & 1054.81 & 428.81 & 102.82 \\
\hline \multirow[t]{2}{*}{ Park G } & U-238 & 28.74 & 42.48 & 12.72 & 5.99 \\
\hline & Th-232 & 48.44 & 68.74 & 29.6 & 9.19 \\
\hline
\end{tabular}

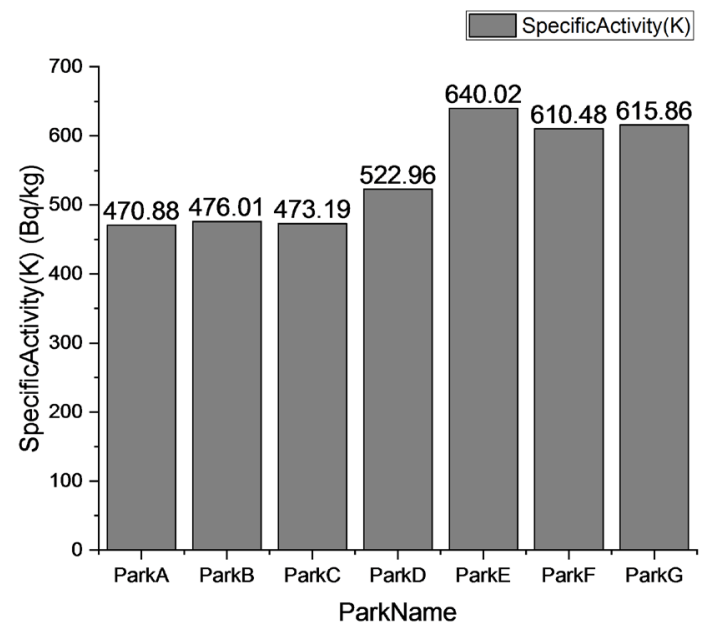

Figure $1 .{ }^{40} \mathrm{~K}$ Specific activity. 


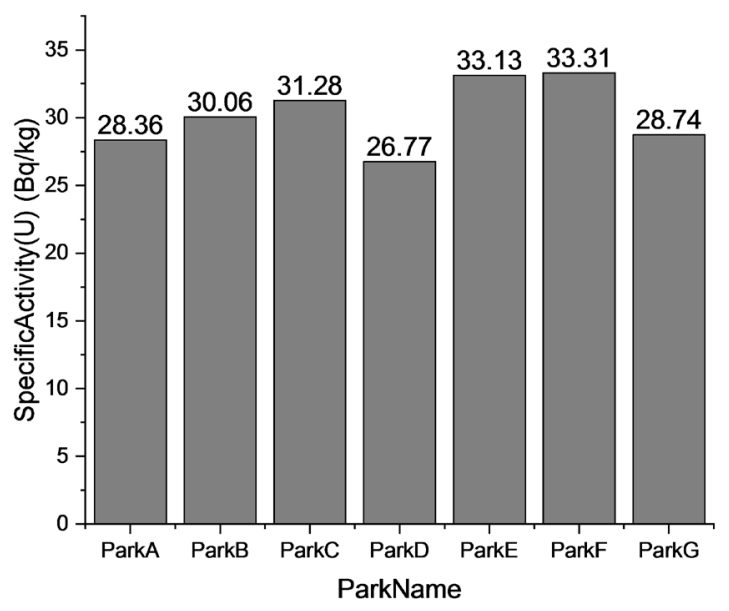

Figure 2. ${ }^{238} \mathrm{U}$ Specific activity.

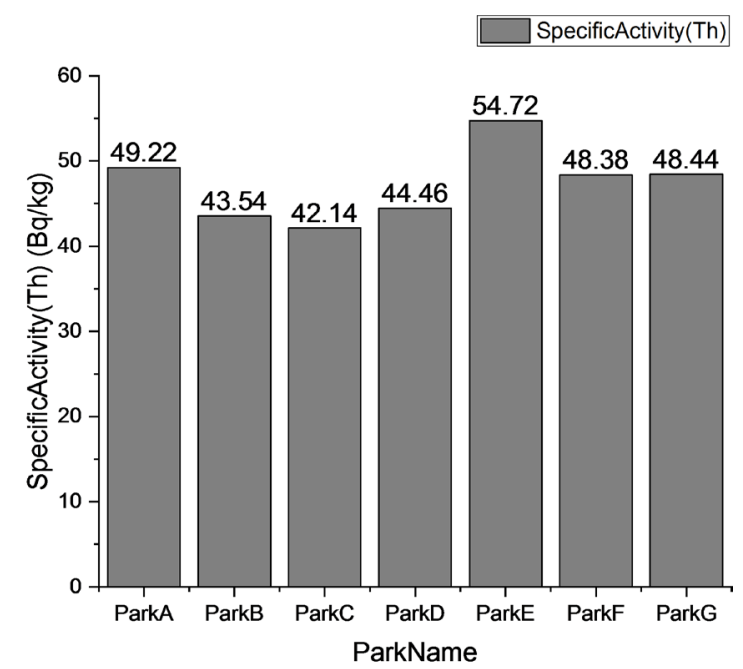

Figure 3. ${ }^{232} \mathrm{Th}$ Specific activity.

Table 3. Comparison of radionuclide content with national average.

\begin{tabular}{cccc}
\hline & ${ }^{40} \mathrm{~K}(\mathrm{~Bq} / \mathrm{kg})$ & ${ }^{238} \mathrm{U}(\mathrm{Bq} / \mathrm{kg})$ & ${ }^{232} \mathrm{Th}(\mathrm{Bq} / \mathrm{kg})$ \\
\hline Park & 544 & 30.2 & 47.2 \\
National average & 584 & 38.5 & 49.1 \\
\hline
\end{tabular}

to $640.2 \mathrm{~Bq} / \mathrm{kg}$; the specific activity content of ${ }^{238} \mathrm{U}$ ranges from $26.77 \mathrm{~Bq} / \mathrm{kg}$ to $33.31 \mathrm{~Bq} / \mathrm{kg}$; the specific activity content of ${ }^{232} \mathrm{Th}$ ranges from $42.14 \mathrm{~Bq} / \mathrm{kg}$ to $54.72 \mathrm{~Bq} / \mathrm{kg}$.

2) The radionuclide content in soil samples in the park is much lower than that of ordinary building materials.

3) The survey area is a natural radiation safe area suitable for human life. People can walk in the park, relax and exercise in their daily life, without causing harm to the health of residents. 


\section{Conflicts of Interest}

The authors declare no conflicts of interest regarding the publication of this paper.

\section{References}

[1] Dai, J.R., Zhi, C.D. and Chao, Y. (2012) Characteristics of Surface Natural Radioactivity Level and Its Main Controlling Factors in Qingdao. World Nuclear Geology, 29, 173-182.

[2] Unsco. (1988) Exposures from Natural Sources of Radiation. United Nations, New York.

[3] Li, R.Y. and Wang, Y.X. (1999) Discussion on Issues Related to Environmental Radiation. Environment of Sichuan, No. 2, 3-5.

[4] Yu, Y.F. (1993) Introduction to Environmental Radioactivity. Fudan University Press, Shanghai.

[5] Wang, W.X., Yang, Y.X., Wang, L.M., Liu, Q.C. and Xia, Y.F. (2005) Studies on Natural Radioactivity of Soil in Xiazhuang Uranium Ore Field, Guangdong. China Environmental Science, 25, 120-123.

[6] Dong, T. (2019) Analysis on Changes of Soil Radionuclide Content in Main Cities of Xinjiang. Drought Environment Monitoring, 33, 125-129.

[7] EJ/T 363-2012. (2013) Specification for Ground Gamma Spectrometry Measurement.

[8] Ruan, S.Z., Zhao, Z.X., Su, K.J., et al. (2017) Investigation and Analysis of Soil Radionuclide Level in Main Parks of Tianjin City. Chinese Medical Equipment, 14, 83-86.

[9] National Environmental Natural Penetration Group. (1992) Investigation on the Content of Natural Radionuclides in Soil in China. Radiation Protection, 2, 132-138. 